\title{
STRATEGIC APPROACH FOR OPTIMIZING OF ZAKAH INSTITUTION PERFORMANCE: CUSTOMER RELATIONSHIP MANAGEMENT
}

\author{
Estu Widarwati ${ }^{1}$, Nur Choirul Afif ${ }^{2}$, Muhamad Zazim $^{3}$
}

\begin{abstract}
Strategic Approach for Optimizing of Zakah Institution Performance: Customer Relationship Management. Zakahh is part of the Indonesian economy, which requires the development and structuring. The funds of zakah must be well managed by organizational zakah system which should be improved its performance. Therefore, there is a need of new approach concerning the zakah management based on muzakki's behavior as an important resource in zakah institution. This paper explores the role of Customer Relationship Management (CRM) in zakah institution linked the important of muzakkis contribution who use services of its. Then it aims to expand the understanding about how CRM as one of strategic approach for organization such zakah institution to improve its performance which employes three main aspect of CRM, which are form of personnel (behavior of personnel), business process, and using technology. Furthermore, this paper tries to depict how CRM is able to raise the zakah funds collection from Moslem society especially Middle Class Moslem in Indonesia by customer (muzakki) satisfaction and cost reduction of zakah institution.
\end{abstract}

Keywords: customer relationship management, zakah institution performance, zakah system, customer loyalty

\begin{abstract}
Abstrak. Pendekatan Strategi untuk Optimalisasi Kinerja Lembaga Zakat: Customer Relationship Management. Zakat merupakan bagian perekonomian Indonesia yang memerlukan pengembangan dan strukturisasi. Dana zakat harus dapat dikelola lebih baik oleh sistem organisasi zakat yang seharusnya ditingkatkan kinerjanya. Hal itulah yang memunculkan adanya kebutuhan pendekatan baru yang fokus pada manajemen berbasis perilaku 'muzakki' sebagai sumber daya input dalam lembaga zakat. Paper ini mengekplor Customer Relationship Management (CRM) pada lembaga zakat terkait dengan pentingnya kontribusi muzakki' sebagai pengguna jasa lembaga zakat. Paper ini bertujuan pula untuk meluaskan pemahaman mengenai bagaimana CRM sebagai salah satu strategi bagi organisasi seperti lembaga zakat dalam meningkatkan kinerjanya di mana ada tiga aspek utama dari CRM yang perlu dikelola yaitu para karyawan, proses bisnis, dan penggunaan teknologi. Lebih lanjut, paper ini mencoba menggambarkan bagaimana CRM mampu meningkatkan pengumpulan dana zakat dari masyarakat Muslim Indonesia khususnya Muslim kelas menengah melalui kepuasan konsumen (muzakki) dan pengurangan biaya lembaga zakah.
\end{abstract}

Kata kunci: customer relationship management, kinerja lembaga zakat, sistem zakat, loyalitas konsumen 


\section{Introduction}

The potentional of zakah funds in Indonesia are relative high, but the amount that has been collected by zakah institutions is less than one percent of the potential funds. In fact, if it is managed organizationally, the zakah funds can increase the standard living of poor people in Indonesia. Especially, Investor survey shows that there is a trend of zakah behaviour in Indonesian middle class moslem that state 'give more, rich more'. The total zakah are an acumulation of some ZISWAF institution (Zakah, Infak, Sedekah, Wakaf) such as Dompet Dhuafa, Rumah Zakah, PKPU and other ZISWAF institutions. According to BAZNAS data, there is an increasing amount of zakah in Indonesia which average level at $24 \%$ per year and Central bank said that zakah fund potential in Indonesia almost IDR 217 billion per year in 2015 or $3.4 \%$ of Product Domestic Bruto (PDB), while only IDR 2.7 billion per year absorbed. It shows trend of public awareness increase for paying zakah to zakah institusion that seems to be proportional to the increasing of economic standard Muslims in Indonesia which linked with resurrection and additions of Middle class of Muslim (Filantropi Islam and Civil Society, Republika, 18 September 2008).

Middle class of Indonesian Muslims increasingly aware that zakah have a role of "driver" for economic growth. Investor survey in 2013 shows that expenditure of zakah and other donations from middle class Muslim in Indonesia almost 5.4\% of total expenditure of months which higher than obligations imposed which are 2.5\%. Indonesian muzakki behavior moves to using technology as a second option in addition to cash payment. Thoriq Helmi as one of director in Dompet Dhuafa said that zakah and other donations in Dompet Duafa dominated by middle class moslem that potential of them doing zakah is great and grow every year, which more than $90 \%$ of them pay the zakah by electronic channel such as transfer or debit bank account. Therefore, this potential need maintenance and development without ignoring conventional system of zakah collection by cash payment that direct to mustahiq.

Generally, Indonesian middle class moslem are knowledgeable that make them be more critical and want a better thing include zakah collecting and its distribution, so do others programs of it. Therefore, a better program innovation of zakah institution need to be improved for customer such as muzakki satisfaction middle class Moslem that has a routine zakah payment electronically. It is a need of new approach concerning the zakah management is based on muzakki's behavior that is an important resource in zakah institution. Customer Relationship Management may be one of alternative ways for an effective fund raising of zakah that understanding consumer behavior can make optimized zakah collecting.

The truth is that the organizational management of zakah should to keep 
and increase its performance, so that the zakah funds can reach as many muzakkis as possible. Among the shortcomings of the organizational collection of zakah funds are: (1) Zakah funds still unstable and reach only a few group. (2) The data of muzakki are still unmanageable. (3) The collection of zakah funds is still not optimized. Zakah institution in Indonesia faces some obstacles for optimizing potential zakah. Muzakki seems having different structure of zakah payment, which linked their behavior, and principles of zakah fund meaning. These must be solved by zakah institution by understanding its customer or muzakki from their behavior with different level of income and habits will give a different custom of zakah payment such Indonesia's middle class moslem to be more comfortable using high technology i.e. transfer system for their zakah payment.

The relationship between consumers and service providers are essential for increasing the services quality and taking the customer loyalty. (Amir et al. 2014) had research in banking industry of East Azerbaijan implied Customer Relationship Management (CRM), which focus on key customers, knowledge management, organizing business process, and using updated technology. The result shows that the use of customer relationship management systems can give an impact on customer loyalty and its dimensions such as focus on key customers have no significant relationship with customer loyalty, but its other dimensions such as organizing the business process, using updated science and technology have a significant relationship with customer loyalty. The study of (Long et al. 2013) in Department Store of Iran uses four critical CRM elements which are measured in this study there are behavior of the employees, quality of customer services, relationship development and interaction management. The finding shows that behavior of the employees is significantly relate and contribute to customer satisfaction and loyalty. Therefore, (Abdolhosseini, et al. 2012) investigated the impact of CRM on customer loyalty and retention in the telecom industry in Iran and found that commitment and vision of the management system is highly required for a successful CRM implementation. Moreover, study by (Kurniati et.al. 2015) defined CRM as customer relationship marketing and found a significant effect on customer loyalty in Mandiri sharia banking in East Java. Some research such (Sin et al. 2005) and Akhavan and Haideri (2008, provided competitive approach by developing the conceptual model of customer relationship management based on knowledge management for its successful implication.

In our knowledge, there is no research yet which focus about implication of Customer Relationship Management (CRM) in zakah institution mechanism. Based on last research and phenomenons of zakah institution performance linked middle class Moslem's behaviors in Indonesia, this paper concern to describe the 
three potential elements of Customer Relationship Management (CRM) in zakah institution. They are quality personnel, management process, and updating of used technology. However, zakah funds management in Indonesia should be directed to organizational customer relation management of the zakah funds, and development its performance by understanding muzakki's behavior as consumer of zakah collection which is managed organizationally will make an impact on the empowerment of muzzaki's satisfaction and loyalty.

\section{Literature Review}

Islamic organization system is an important part to discuss in this paper. It has its significant place in Islam, as Allah loves those who perform the struggle in His way of life in proper and well-organized way with full responsibility and efficiency. In fact, without have a clear understanding about the organization system, we will not be able to develop our organization in order to obtain the objective. The organization gist is the interaction or communication between the people, which is embodied in a form in order to obtain the same objective (Hafidhuddin and Tanjung, 2002).

The managements of zakah funds in the world are varied and depend on each prevailing system in the respective countries. There are countries that apply mandatory system with collective management, such as Saudi Arabia, Pakistan, and Malaysia. There are also countries apply voluntary system with collective management. The other countries apply voluntary system with individual management. Based on the table below, several countries apply monopoly in their zakah management, while several others, the governments and communities have the same involvement in zakah management and distribution.

Table 1 Pattern of Zakah Management in the Contemporary Muslim Community

\begin{tabular}{cll}
\hline No. & Collection and Management Pattern & Country \\
\hline 1. & Mandatory system with collective management & Saudi Arabia \\
& & $\begin{array}{l}\text { Pakistan } \\
\text { Malaysia }\end{array}$ \\
2. & Voluntary system with collective management & Singapore \\
& & $\begin{array}{l}\text { Indonesia } \\
\text { Non-Muslim countries }\end{array}$ \\
3. & Voluntary system with individual management & Indonesia \\
\hline
\end{tabular}

Source: Wibisono (2015) 
To increase the benefit reachability of zakah throughout Indonesia, the implementation of management science is necessary to take into a note, so that the zakah funds distribution can go effectively in reaching each mustahiq. In Islam, there are two groups: muzakki and mustahiq. The muzakki group consists of those who are obliged to pay for zakah, while the mustahiqs are those who have rights to get zakah fund. Zakah management pattern should be directed to organizational pattern (Widarwati and Afif, 2015). The following is among the characteristics of organization: (1) Long-term. (2) Having vision, mission, and objectives. (3) The formal relationship more dominates than the non-formal one. (4) Personal relationship more dominates than non-personal one. (5) Right man in the right place. (6) Having divisions of duties, authorities, and responsibilities.

Thus, if zakah funds are managed organizationally and not temporarily, the treatment for muzakki and mustahiq can go sustainably. Zakah management can also be focused based on the vision, mission, and purposes determined. In human resource management, there are also punishment and reward by placing the persons according to their respective competences. Every member of the zakah management organization has also strict divisions of tasks, authorities, and responsibilities.

As we know, customer access to various channels of information and data distribution, and presenting goods or services for selecting of its in a compact and highly competitive environment in the market, have reduced their loyalty towards suppliers. Therefore, there should be a way for effectively communicate with clients and their survival is one of the most important issues in durability and stability of companies in the area of competitiveness and profitability (Teorandic, 2002). Also, given that in recent years, customer expectations have increased in today's customer oriented business conditions, customer relationship management is a necessity (Thompson et.al, 2006).

Today, many firms invested heavily on customer relationship management on reason that the challenges the prevailing business environment, organizations are not only trying to attract new customers but also adopted the strategy of keeping existing customers and improved their loyalty to the organization. Therefore, establishing long-term relationships is aimed in order to retain more customers and ensure the long-term market share and sustainability of the organization (Amir et al. 2014).

However, the applications of the concept of Customer Relationship Management in various fields, especially in the service sector is undeniable and cannot be ignored due to the difficulties and risks. Given the high importance of the implementation of customer relationship management in zakah institution, 
which is one of the major tools to compete and sustainable efficiency advantage a proper mechanism should be developed and designed to help reduce the risk of unsatisfaction muzakki and unmistaken distribution of zakah and other donation for optimal its performance.

One of the reasons for the failure of CRM implementation that different researchers have pointed out, is the Lack of tools and criteria for measuring and evaluating the relationship with customers, this concept of the organization as well as other concepts cannot be managed properly without being measured, Thus, a comprehensive tool for assessing the relationship with customers is essential (Amir et al. 2014). Hence, a comprehensive tool for assessing the relationship with customers is essential.

According to studies, aspects of the Customer Relationship Management linked with the characteristic of zakah institution, they are: First, forming of quality personnel; Behavior of the Employees is important for organization performance. An employee that comfort with organization behavior and value is likely to strengthen the connection between the consumer and the firm (Long et al. 2013). A reverse pattern of effects is to be expected when the employee act through his/ her own behavior. In these cases, a consumer may think that the organization actually does not deliver the symbolic benefits that she had expected for and may evaluate the organization in a negative way. In other words, under circumstances such as the ones described, an employee will probably exert a strong impact on organization reputation and attitudes (Coulter \& Coulter 2002). According to the works of (Hanley et al., 2009) and (Coulter \& Coulter 2002), the effect of positive employees' behavior could be expressed by increasing speed of response to customer and ensure employees are friendly and respectful to customer.

Second, organizing the business process; Processes of customer relationship management requires a change in the organization and the business process structure. For this purpose, organizational structure, organizational commitment and human resource management are important (Agarwal, 2004). An issue that should be considered is commitment in the organization. Success in attracting and retaining customers depends on the commitment of resources to identify and meet the needs of key customers (Nycampa, 2001). Third, using up-dated technology; Computer Technologies are used in developing computerized communications and technology aligned with business objectives. The use of customer relationship management software enables companies to customize services to provide a higher quality and lower cost. It also leads employees to work better with customer contact points (Zineldin et all, 2005).

Customer Relationship Management (CRM) is a concept for managing a 
company's interactions with customers, clients, and sales prospects. It involves using technology to organize, automate, and synchronize business processes. It is necessary to put the customer at the Centre of the business according to its strategies, events and processes. Organizations are setting themselves strategies to ensure customer retention, and changing their employees to be more customerfocused and service-oriented (Mohsan et al. 2011; Al Arif \& Nurasiah, 2015). The objectives of CRM are to enhance efficiency, customer satisfaction, and customer loyalty.

Loyalty is one of key concepts in marketing management that plays an important role in creating long-term benefits for the organization because loyal customers do not require extensive promotion efforts. Customer loyalty is important in different aspects. Loyal customers help the organization in determining the expected increase in sales and profit. In addition, customers who are familiar with the brand are likely to recommend it to their friends and relatives and affect the feedback and evaluation cycle of the product and these issues are critical in today's business environment (Allameh and Noktedan, 2009).

There is a significant positive relationship between the quality of service encounters and service quality, customer satisfaction, and perceptions of the quality of his service encounter between perceived service quality and customer satisfaction and perceived service quality and customer loyalty, and loyalty customer and employee loyalty to the organization, customer satisfaction and customer loyalty among employees (Makizadeh et al., 2009). Seyyed (2006) stated that the main factors influencing customer loyalty were based on the management model including customer relationship in the form of personnel, processes and technology. The success of customer relationship management is based on four factors of focus on key customers, organizing the $s$ our factors focus on key customers organize, knowledge management, and using updated technology (Sin et al. 2005).

However, muzakk'si loyalty needs be maintain by good service of zakah institution. Therefore, they will have high trust and believe on governance in zakah system of organizational zakah both collecting and distribution. Furthermore, muzakki's loyalty will be a strong reason for zakah institution to do the best in increasing its performance by adding other quality programme and improve its role in reducing poverty as its main goal.

\section{Methods}

This paper is exploratory study that try emphasizes the collection of ideas and suggestions, especially to solve the broader problems in order to become 
narrow and proper. For exploration of new approach in zakah institution by CRM which focus on muzakki's behavior, this paper had some steps there are: (i) Formulating a problem, which concludes by literature reviews of last study results about zakah institution and its performance. (ii) Determining the priority for the following research by searching more potential weakness from zakah institution performance. (iii) Collecting the relevant information about some facts or phenomena of zakah institution and its performance linked relationship of muzakki. (iv) Increasing the opportunity analysis of the solution problem faced in zakah institution. (v) Explaining the new approach Customer Relationship Management (CRM) concepts of zakah institution performance improvisation from analysis done.

\section{Result and Discussion}

A new approach of exploring potential muzakki and to maintain their satisfaction and loyalty of zakah institution's services is by managing the relationship between zakah institution and muzakki. A great quality of service and good governance of zakah system will make muzakki in belief for giving their zakah and other donation to zakar institutions regularly and continuously.

Customer relationship management is a process consisting of monitoring clients, collecting proper data, management and evaluation of data and finally real advantage of the extracted data in their interactions (Kim et al, 2010). The main goal of customer relationship management is simply better understanding of customer behavior and enhances loyalty (Kimiloglu \& Zarali 2009).

This paper concern to a new approach, which is Customer Relationship Management (CRM) for optimizing collection zakah fund of muzakkis in Indonesia that distribute zakah to institution. It is shown in Figure 1

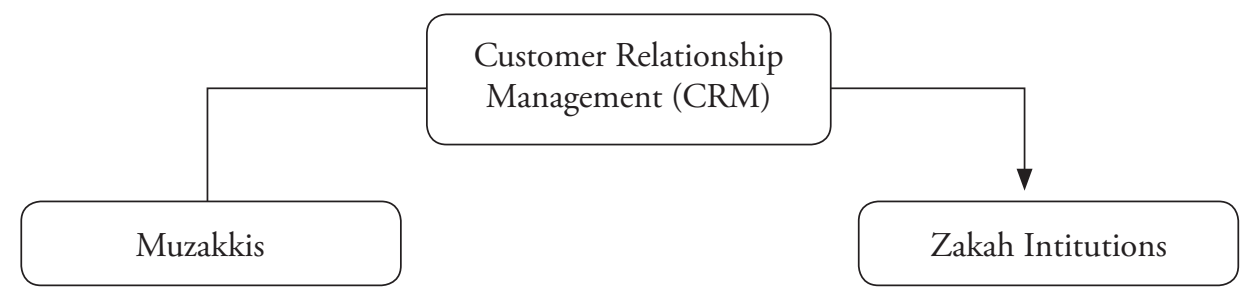

Figure 1: Zakah System by Implementation CRM For Optimizing Fundraising of Muzakki

According to the theoretical framework suggested in Figure 2, the role of Customer Relationship Management to optimizing zakah institution's performance 
by a focus on three main aspect citied from (Amir et al. 2014) for aspect forming behavior personnel, and (Long et al. 2013) for both aspect of organizing business process, and using updated technology. These aspects relationship will be explained in terms model linked muzakki's satisfaction and loyalty.

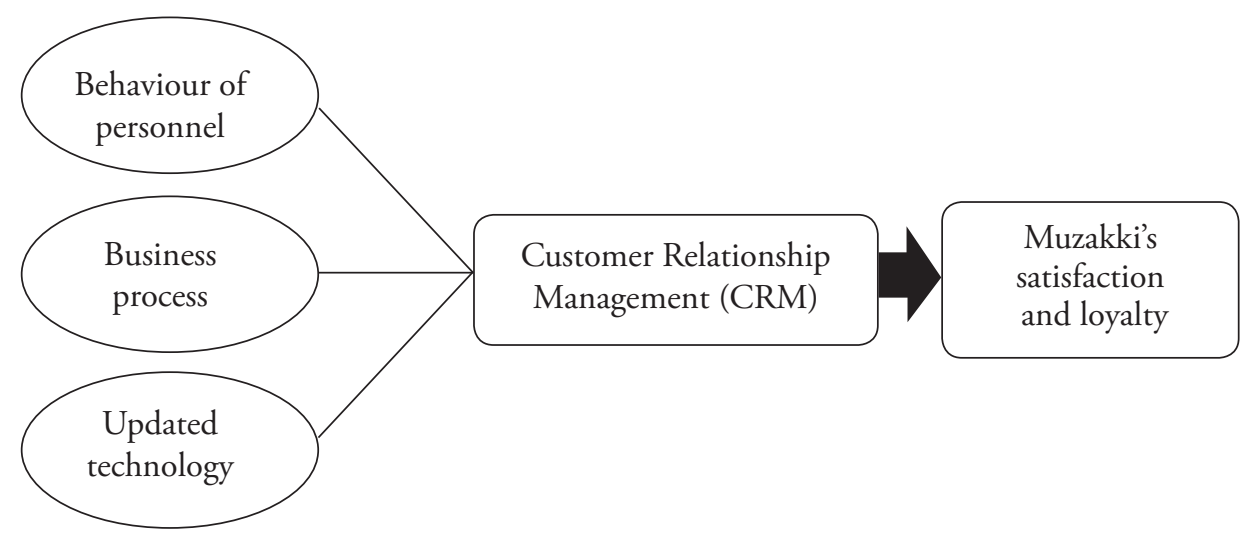

Figure 2: The Role Customer Relationship Management To Muzakki’s Satisfaction and Loyalty

Figure 2 explain that behavior or forming of zakah institution personnel that described by institution of zakah will probably exert a strong impact on organization reputation and attitudes. The kindness, capabilities, and ethic given to muzakki will support arising of customer satisfaction because they are serviced well. Therefore this effect direct to muzakki's loyalty for payment of its zakah fund or other fund to zakah institution that preferred. Furthermore, implementation of customer relationship management requires a change in the zakah institution in both process and structure. The organizational commitment and human resource management be important things as requirement for a successful CRM in organization include zakah institution. The zakah organization should identify the key needs of muzakki then the services given by personnel will be match with muzakki's willing. The structure of the strategy should be based on flexibility and explicitly of the policies especially policies of taking fund and its cost (Abdolhosseini, et al., 2012). All these both of personnel 's behavior and business process must be supported by a good updating of technology. As we know, the trending of middle moslem in Indonesia that use some modern application of system payment in their daily activities as debit card, e-banking, and other kind. The zakah institution should give a complete service for their customer then they muzakki) can make easier payment of zakah and other funds by short time and flexible access. 
CRM is implemented in an organization to reduce cost and increase company performance. Indeed, in a successful CRM implementation, data are collected from internal and external source such as customer service, marketing, procurement, and others. The customer perception and treatment given to each customer individually able to assist in solving many customers' problems. Thus, customer satisfaction and loyalty would be achieved through a successful CRM implementation. Therefore, organization should discover different requirements of the customers and adjust their policies according to their needs to increase the firm's competitiveness (Bhattacharya 2011).

However, the aim of CRM implementation in zakah institution is to maintain muzakki as its customers and increase their loyalty. Muzakki's satisfaction and pleasing are two main elements in a successful CRM implementation for retaining muzakki's loyalty to a zakah institution. Behavior of the personnel's are also play significant role in increasing customer loyalty. The organization must put emphasis in the two elements that are behavior of personnel's and relationship development. Personnel or employees are expect not merely be polite and courteous towards their customer, but most importantly must have the product knowledge and communication skills that can create a relationship with the.

The positive employees behavior is vital in sustaining customer's loyalty. Employees must be trained to response to the customers' needs in an appropriate speed. They must also able to show concern and care to the customers. Behavior change can only be done if management team is serious in investing in their human capital. This can only be done through series of training and developmental programs for the employees. By improving the competencies of employees in this area will definitely improve the overall service quality of the organization. Organization must also constantly keep their employees motivated because highly motivated people would definitely able provide better services (Hanley et al. 2009; Coulter \& Coulter 2002).

The other things that can support a well new concept of CRM in zakah institution are Islamic perspective framework of Marketing. Islam encourages the people to make some explorations in the business activities. Evidently, the Prophet Muhammad PBUH used to deal in business on the expense from Khadijah, and as a return she also received a lot profit. In the history of the Prophet, we attempt to analyze some significant lessons that can be demonstrated in the Islamic organization. Basically, we need to know among the characteristics of the Prophet Muhammad PBUH, which are honesty, true-worthiness, cleverness, and message deliverer. Hence, the Islamic organization should be based on these values in their 
transaction. Besides, we may also recover his other important characteristics that can ensure the stability of an Islamic organization. According Yuswohady (2014), marketing program for a special customer such middle class Moslem is different. There are some principles that can make an optimizing success service of zakah institution:

(1) The Principle of Customer: Understanding customer behavior. Muzzaki as customer of zakah institution become more religious and they begin to search for spiritual value. The institution of zakah must give product or service that have a compliance product or service to Islamic value. (2) The Principle of Competition: Competition is about building brand personal. Connect institution brand to the customer's heart. The institution of zakah should understand each group of muzakki's characteristic that can know how to treat them. Beside it, zakah organizations must build personification based their characteristic and create emotional and spiritual connection with them. (3) The Principle of Positioning: Be a Universal Icon. The zakah institutions should kindly for all muzakki, open-minded for information, idea, and other thinking, be positive that complete in goal (universal goodness). (4) The Principle of Differentiation: Build authenticity through commitment and passion. The zakah institution must put on universal Islamic value as "reason for being" and it should try some efforts universal goodness as "what the business are we in". (5) The Principle of Value: Offer unique universal value. The zakah institution should can give universal value which is combination between functional, emotional, and spiritual that divided by costs expenditure. (6) The Principle of Engagement: Connect your customers to each other, Moslems are social group having a shared purpose to reach the safety of the world and the hereafter by always running the commands of Allah and avoid His bans. Then a great marketing approach for these communities is by community marketing that connects each consumer with others in one community.

\section{Conclusion}

Based on the discussion above, it can be explained that zakah institutions should improve their fundraising or collecting zakah funds management which considerate a Customer Relationship Management (CRM), so its performance such cost efficiency can be increased. CRM has some advantages, such as the continuity in satisfaction and loyalty of muzakki, an effective zakah distribution and also the zakah management can be more focused on vision, mission, and objectives determined. Externally, there is policy implication of this CRM's approach for zakah institution strategy is legality law for getting support data system of muzakki 
from other institution such financial institution or government's zakah institution that have data of zakah fund transfer and can show the muzakki's behavior in their zakah payment habits both time and amount. Therefore, internally, however, the success implementation CRM depend on three main aspects of CRM that should be improved by changing zakah institution's strategy linked forming of quality personnel or behavior employee, organizing business process, and using updated technology.

\section{References}

Abdolhosseini, A.K. et.al. (2012). The Impact of eCRM on Loyalty and Retention of Customers in Iranian Telecommunication Sector. International Journal of Business and Management. Vol. 7(2): 150-162.

Agarwal, A. et.al. (2004). Organizing for CRM. McKinsey Quarterly. Vol. 3: 80-91.

Akhavan, P \& S. Heydari. (2008). Customer Knowledge Management Approach to Gain a Competitive Advantage. Management Tomorrow. Vol. 18: 55-69.

Al Arif, M.N.R. \& T. Nurasiah. (2015). Customer Relationship Management dan Pengaruhnya Terhadap Loyalitas Nasabah Bank: Studi Pada Bank Muamalat Indonesia. Esensi: Jurnal Bisnis dan Manajemen. Vol. 5 (1): 51-64.

Allameh, M. \& I. Noktedan. (2010). The effect of service quality on customer loyalty (case study of four and five star hotels). Business Management. Vol. 2(5):109-124.

Amir, M. et.al. (2014). The Effect of Using Customer Relationship Management System on Customer Loyalty Case Study: Ansar Bank's Branches in East Azarbaijan. Indian Journal of Scientific Research. Vol. 8(1): 98-106

Bhattacharya, A. (2011). Preeminent Analysis Of Customer Relationship Management (CRM). International Journal of Research in Management and Technology (IJRMT). Vol. 1(1): 45-51.

Coulter, K.S. \& R. Coulter, R. (2002). Determinants of trust in a service provider: The moderating role of length of relationship. Journal of Services Marketing. Vol. 16(1): 35-50.

Hafidhuddin, D. \& H. Tanjung. (2003). Manajemen Syariah dalam Praktik (Sharia Management In Practice). Jakarta: Gema Insani Press.

Hanley, S. et al., (2009). The effectiveness of relationship marketing strategies in department stores. International Journal of Business and Management. Vol. 3(3): 226-234. 
Kim, H.S et.al. (2010). Integration of Firm's Resource and Capability to Implement Enterprise CRM: A case study of a retail bank in Korea. Decision Support Systems. Vol. 48: 313-322 .

Kimiloglu, H. \& H. Zarali. (2009). What signifies success in e-CRM? Marketing Intelligence \& Planning. Vol. 27(2):246-267.

Kurniati, R.R. et.al. (2015). The Effect of Customer Relationship Marketing (CRM) and Service Quality to Corporate Image, Value, Customer Satisfaction, and Customer Loyalty. European Journal of Business and Management. Vol. 7(11): 107-120.

Long, C.S. et.al. (2013). Impact of CRM factors on customer satisfaction and loyalty. Asian Social Science. Vol. 9 (10): 247-253.

Makizadeh V. et.al. (2009). Examine The Relationship Between Service Quality and Customer Loyalty in The Face of Commercial Services. Landscape Management. number 32: 121-130.

Mohsan, F. et.al (2011). Impact of customer satisfaction on customer loyalty and intentions to switch: evidence from banking sector of Pakistan. International Journal of Business and Social Science. Vol. 2 (16): 263-270.

Nykamp, M. (2001). The Customer Differential: The Complete Guideto Implementing Customer Relationship Management. New York: AMACOM.

Seyyed, S.RJ. (2006). To Determine The Factors Affecting Customer Loyalty Export Development Bank of Iran: Using The Concept of Customer Relationship Management. Business Review. No. 18: 91-82

Sin, L.Y.M. et.al. (2005). CRM: conceptualization and scale development. European Journal of Marketing. Vol. 39: 1264-1290.

Theorandic, R.L. (2002). Customer relationship management(CRM) in Financial services. European Management Journal. Vol. 18 (3): 312-327.

Thompson, S.H. et.al. (2006). Towards a holistic perspective of customer relationship management (CRM) implementation: A case study of the Housing and Development Board. Singapore Decision Support Systems. Vol. 42: 1614-1620.

Wibisono, Y. (2015). Mengelola Zakah Indonesia: Diskursus Pengelolaan Zakah Nasional dari Rezim Undang-undang Nomor 38 Tahun 1999 ke Rezim Undang-undang Nomor 23 Tahun 2011. Jakarta: Prenada Media Group.

Widarwati, E. \& N.C. Afif. (2015). Building of Organizational Based Zakah System In Indonesia. Proceeding Paper of The 2nd International Convention On Islamic Management 2015, Academy Of Islamic Studies, University of Malaya. 
Al-Iqtishad: Jurnal Ilmu Ekonomi Syariah (Journal of Islamic Economics) Vol. 9 (1), January 2017

Yuswohady. (2014). Marketing to the Middle Class Muslim. Jakarta: Gramedia Pustaka Utama.

Zineldin, M, et.al. (2005). Research and Concepts Quality and customer relationship management $(\mathrm{CRM})$ as competitive strategy in the Swedish banking industry, The TQM Magazine. Vol. 17 (4): 329-344 